\title{
Democracy, Free Association and Boundary Delimitation - The Cases of Catalonia and Tabarnia
}

\author{
Guillermo Graíño Ferrer ${ }^{\mathrm{a} *}$ and Adriaan Ph. V. Kühn ${ }^{\mathrm{b}}$ \\ ${ }^{a}$ Institute for the Study of Democracy, Universidad Francisco de Vitoria, Madrid, Spain \\ ${ }^{b}$ Institute of International Politics, Universidad Francisco de Vitoria, Madrid, Spain
}

Universidad Francisco de Vitoria, Instituto de Estudios de la Democracia, Carretera Pozuelo a Majadahonda, Km 1.800, 28223 Pozuelo de Alarcón, Madrid (Spain). g.graino.prof@ufv.es, Tel. +34 669234949

Dr. Guillermo Graíño Ferrer is a lecturer in Political Theory at the Universidad Francisco de Vitoria, the director of its Institute for the Study of Democracy, and a member of 'The Political Philosophy of the City: Ideas, Forms and Urban Spaces' at the Consejo Superior de Investigaciones Científicas (CSIC).

Dr. Adriaan Ph. V. Kühn is a lecturer in International Relations at Universidad Francisco de Vitoria in Madrid, Spain. 


\title{
Democracy, Free Association and Boundary Delimitation - The Cases of Catalonia and Tabarnia
}

\begin{abstract}
This article aims to illustrate the confusion within today's secessionist movements regarding the liberal and the nationalist arguments for legitimizing secession. To do so, the liberal theory of secession - understood as an approach primarily based on consent - is examined, its limitations highlighted, and its contradictions with nationalism stated. We then use the case of the fictional Tabarnia region to show how problematic the use of liberal arguments by secessionist nationalism is. Although until now only a virtual region, Tabarnia exemplifies how nationalist arguments reappear in the defence of Catalan independence when its supporters claim to advance only (liberal) arguments of free association.
\end{abstract}

Keywords: secession, consent theory, liberalism, Catalonia, Tabarnia,

\section{Introduction}

For most of human history, humankind has lived within an inherited social and political framework over which it has generally been unable to consciously exercise control. The Enlightenment, liberalism and democratic progress may thus be understood as attempts to empower humans with the means to effectively influence the social and political world in which they live. Owing to these ideas, institutions, laws, codes, political practices and traditions have been subject to ever-growing scrutiny.

The role of nationalism in this process is ambivalent. According to Elie Kedourie (1960: 9), nationalism is a doctrine that 'holds that humanity is naturally divided into nations, that nations are known by certain characteristics which can be ascertained, and that the only legitimate type of government is national self-government'. Here, the assumption that the world is 'naturally divided into nations' is contrary to the belief that mankind itself designs its social habitat, and the very idea of a natural division of peoples 
has led to the most well-known catastrophes. However, the nationalist credo states that it is the people who take control over the power arrangement of the ancien régime - often perceived as 'foreign' - or, alternatively, that they cast off the yoke of an empire or colonial power. In these cases, nationalism certainly empowers or aims to intensify political participation for a people that, partially or completely, has previously been excluded from it.

In today's separatist discourse, regarding 1) nationalism as a historic catalyst for the establishment of popular sovereignty and 2) nationalism as a maximalist ideology that seeks the rearrangement of borders based on pre-political assumptions, we find that these two concepts are mixed and confused when they should be analytically separated. Therefore, when today's separatist movements challenge established liberal democracies, they tend to identify the nationalist reorganisation of frontiers (1) with an intensification of democratic government. (2) This 'natural' association between the nationalist and the democratic element was originally proposed by John Stuart Mill (1977 [1861]: 547) in his famous work Considerations on Representative Government: 'Free institutions are next to impossible in a country made up of different nationalities. Among a people without fellow-feeling, especially if they read and speak different languages, the united public opinion, necessary to the working of representative government, cannot exist'. Therefore, within a sociologically aware liberalism that seeks optimum conditions for the founding and survival of representative government rather than establishing abstract principles of individual rights, national integration clearly benefits democracy (Miller 2003: 262-74).

However, it is not only the argument of cultural homogeneity that is advanced by those who seek secession today, for example, in the case of Catalonia. One reason is that to do so would be to employ the very same argument that has traditionally accompanied 
the nation-building processes of large European states, a development that separatists today all but aim to reverse. According to Will Kymlicka (2011: 255-6), a matching between a political border and a national culture can be achieved in two ways: either by rearranging established borders so that they overlap pre-existing cultural spheres of influence by means including secession and annexations (thereby taking for granted that a clear-cut separation in identities is possible) or by engaging in a process of cultural homogenisation within a territory that is already politically formed. Defending that the former way of pursuing a political territory's cultural harmonisation is legitimate, while the latter is not, is the central issue in the separatist discourse.

Hence, separatism today tries to identify itself not so much with the defence of an assumed harmonic relation between culture and polity but with the belief that consensus is imperative for the legitimacy of any given border regime. This consensual rearrangement of the modern nation state's frontiers would thus mean nothing less than the conquest of one of the last strongholds that has prevented mankind from consciously shaping its environment. The alliance between democracy and nationalism is forged by a plebiscitary mechanism inherent to referenda: The 'right to decide' empowers a group of people to determine whether they continue to form part of a state - or not. As symbols of the archaic arbitrariness in which human history evolved, borders would now be subject to democratic accountability. However, in addition to this argument, the traditional nationalist axiom of re-establishing natural harmony is still to be found in the separatist discourse. The vast majority of separatists still defend that pre-political links carry an 'extra' legitimacy over the arbitrary and artificial political relations that were subsequently established.

We suggest analytically distinguishing between two lines of argumentation that are frequently confused: (1) a consensual argument based on the right to decide, i.e., the 
celebration of a referendum, and (2) a purely nationalist argument favouring national independence. Our position holds that the first is also a nationalist argument, in that it does not defend the right to decide for any given strata of a people that hold a common will but, rather, grants the right to decide to a territory that coincidentally matches a set of cultural characteristics that are recognised as such by the very same group of people in the first place.

The first part of this article examines the liberal justification of secession, taking Harry Beran's theory as its clearest formulation. We intentionally ignore remedial right theories, which focus on justice or human rights matters, topics that Allen Buchanan (1991, 2003) explored in his work, because our aim is to analyse and clarify the role of pure liberal theories of secession, which are based only on consent. We then study the case of the fictional region of Tabarnia, where the democratic argument in the secessionist discourse is pushed to its limits in a way that forces the underlying nationalist figure to emerge. Our approach ultimately aims to clarify the relationship between the concepts of sovereignty, nation, and free association in today's discussion of territorial secession.

\section{Secessionism and Free Association}

In our understanding, Harry Beran is the champion of the liberal theory of secession. In his distinction between a 'nationalist' and a 'democratic' reason behind political selfdetermination (which ultimately allows for secession), the elements of a liberal theory of secession, free from any nationalist contamination, are laid out (Beran 1998: 33).

The two most important theories of morally rightful political boundaries are the nationalist and the democratic theory of political selfdetermination. According to the former, it is nations that have the right 
of political self-determination. According to the latter, political unity must be voluntary, and it is democratically self-defined territorial groups that have this right.

In the 'democratic' theory, it is not nations that exercise self-determination but 'selfdefined territorial groups'. This difference is important. While in the nationalist theory the world's division into nations is a pre-political fact, Beran's theory links 'territorial groups' to their members' free expression in the form of a 'self-definition'. Not surprisingly, Beran finds that any attempt at territorial ordinance based on nationalist assumptions is doomed to fail (Beran 1994: 47-65). However, he also holds that the democratic principle should guide the delimitation of political units - which would make secession legitimate in a wide range of cases - an idea that Beran attributes to authors such as Gilbert Murray, Robert Dahl, Thomas Pogge and David Gauthier (Beran, 1998: $34)$.

The starting point of Beran's theory is the postulate that adults bear 'the right of personal self-determination and, therefore, of freedom of association with willing partners' (Beran 1998: 39). Here, a first difficulty emerges: Given the impossibility of totally breaking the linkage between state and territory, it is not the individuals who associate themselves with the latter (not even in Beran's theory) but, rather, some kind of territorially bound human cluster, howbeit ever so small. Individuals cannot choose their affiliation with any political unit individually, at least if one does not consider the possibility of potential universal migration in a borderless world - which, in any case, would then grant an advantage to those whose preferred unit coincides with the territory in which they already live.

Facing the problem that voluntary political association is practically impossible to pursue on an individual level, Beran and other representatives of liberal secession 
theory are forced to establish something that we coin a 'minimum sovereignty unit'. This unit is defined as minimum because it aims to approach as closely as possible the individual right to self-determination. Thus, in Beran's (1998: 40) words, 'the right of a smaller community always overrides the right of the larger community of which it is part, if there is a conflict of wishes regarding political boundaries'. Now, the philosophical problem of how to determine the very last community to which this principle applies is obvious.

The argumentative shift should not be overlooked: The right to selfdetermination is founded in the individual but exercised on a superior level. Therefore, the leap from the individual to the point where self-determination comes into existence might be smaller than in the case of nations, but it still exists. ${ }^{1}$ Beran (1984: 21-31) had first stated, 'liberalism requires that any territorially concentrated group within a state should be permitted to secede if it wants to and if it is morally and practically possible'. Therefore, territorially concentrated groups - regardless of their concrete composition constitute sovereign elements. In a later publication, Beran called these minimum sovereignty units 'territorial communities'. 'Territorial communities' or 'territorially concentrated groups' constitute the first link that individuals establish between themselves and serve as a basis for the superposition of other composite structures. In conclusion, 'individuals have the right of free association, including the right to form territorial communities on land they rightfully hold or acquire' (Beran 1998: 37).

\footnotetext{
${ }^{1}$ It is only in the radical libertarian theory close to anarchism where the transfer is not made. Here, the problem of individual self-determination becomes a mere technical issue, and the right to secession has its last and only foundation in the individual. Cf. McGee (1992, 45-66).
} 
We identify three main problems linked to these postulates of liberal secession: a) the link between individual preference and territorial settlement, b) the delimitation of territories where the majority principle can be applied, and c) the underlying concept of political organisation.

\section{Minimum Sovereignty Units and Free Association}

Liberal theories open to secession - such as Beran's - often imply that the strength of the voluntary link is inversely related to the size of the group in question. Beran speaks of 'the right to form territorial communities', stating that political links should resemble the liberty of choice that characterises marriage or labour relations in liberal democracies. 'Because of liberalism's commitment to freedom as an ultimate value, liberals see the ideal society as one that comes "as close as a society can to being a voluntary scheme"" (Beran 198: 24).

At this point, we think that a couple of questions should be raised: Do individuals really exercise their liberty to establish themselves in a given territory according to their associative preferences? Does a society better meet the ideal of voluntary association if the dominant political link between its members is based on low-order vicinity instead of, say, nationality? These beliefs do not seem to respond to the way in which humans, until today, have settled in any given territory: Association is often the result of previous vicinity, while vicinity is normally not the consequence of associative preferences. Now, from Beran's liberal perspective, one could argue that this statement describes only the ideal situation, that in which free association is a key element of every kind of political and social linkage. Importantly, however, even in that case, every change of vicinity would then mean a relevant change of association, which in turn would break the great agility and ease of settling that characterises modern states, inhibiting instead of 
facilitating individual movement. This inhibition is one of the paradoxically illiberal consequences of the maximalist approach to consent in liberal theory.

In summary, for Beran's theory to be appropriate, association should be the first motivation for settlement. In that case, political institutions would gain in consensus, while individual territorial movements would be more significant - but become more strenuous.

\section{The Relationship between the Majority Principle and the Delimitation of}

\section{Boundaries}

For liberal secessionism, climbing down the ladder of the diverse levels of majority rule still the preferred way of ultimately determining the voluntarist nature of political relations. Thus, the smaller the size of sovereign units is, the better the correspondence between boundaries and individual preferences. These territorial units operate as entities that can associate between themselves; however, while decision-making still resides on this (last) level, individual preferences ultimately draw the political map.

In other words, with the majority principle operating amongst minimum sovereign units, a better matching between individual preferences and state affiliation would be possible. Therefore, when democracy heads towards the liberal principle of free association, it should reduce the size of decision-making units where majority rule is applied. 'The reiterated use of the majority principle to settle disputes about political borders $[\ldots]$ maximizes the number of individuals who live in mutually desired political association, an ideal implicit in the right of freedom of association' (Beran 1998: 39).

However, any limitation on the scope of a given sovereign unit does not eliminate the underlying pre-democratic character of its original demarcation. Regardless of 
transferring it to a lower level, the problem of delimitation remains intact. Who, then, defines the precise limits of territorial communities?

The reiterated use of the majority principle to settle disputes about political borders always yields a determinate result. It therefore provides an adequate response to Ivor Jennings' quip (1956: 56) that 'the people cannot decide [issues of political boundaries] until someone decides who are the people' (Beran 1998: 39).

From our perspective, Ivor Jennings has a point. The majority principle offers a clear-cut result at all times, even though its area of application must be previously defined. Therefore, there is no conceivable way in which the majority principle can evade an important pre-democratic supposition: the exact delimitation of the matter of who. Any vote requires a previous idea about the concrete boundaries of the sovereign unit (howbeit ever so small) that the ballot addresses. This delimitation may be constructed around a forecast or an educated guess about the will to associate of a given people, not by strictly applying the majority principle.

Some authors distinguish between a liberal and a democratic theory of secession (de Lora 2018). We believe that this distinction is confusing precisely because of the different possible ways in which to determine who the people is. The question of the application of the majority rule in the case of the delimitation of territory may be answered in two ways that justify secession: 1) the nationalist option ('the nation itself constitutes the legitimate delimitation') or 2) the liberal option ('any minimum sovereignty unit constitutes a possibly legitimate delimitation'). Therefore, for Beran's 'democratic', we understand 'liberal', and we identify today's separatist discourse with the nationalist option. 


\section{The Right to Secession and the Nature of Political Organisation}

At this point, it is important to stress that a pure realisation of the theory in question would not lead to the secession of a somehow identified peripheral nation but to a wider political fragmentation. The ultimate perspective is one of territorial discontinuity that calls into question elementary state functions. Beran proposes an intellectual experiment in the case of the former state of Yugoslavia concerning the application of the majority principle in territorial communities:

Some of the borders of the republics of the former Yugoslavia would have been substantially redrawn. Many Serbian communities in BosniaHerzegovina and Croatia would, no doubt, have joined Serbia. Some Croatian communities in Serbia and Bosnia-Herzegovina would probably have joined Croatia (Beran 1998: 51).

Therefore, 'some states may end up with two sorts of enclave: small independent microstates, and pockets of territory that belong to another state' (Beran 1998: 51). In cases in which a minimum sovereignty unit does not coincide with state boundaries, resulting in the fragmentation of the state into a multitude of sovereign units, one can indeed expect a territorial realignment in favour of microstates and territorial particularism.

In Beran's view, his theory 'is intended to be compatible both with versions of democratic liberalism and of democratic socialism' (Beran, 1998: 34). However, it would be more accurate to speak of a genuinely new political model whose consequences appear to be compatible only with libertarianism. Issues such as the provision of infrastructure for vast territories, the question of property rights regarding natural resources, and the logic of patronage resulting from the potential mobility of high political associations 
would lead to a very different polity model compared to that which modern states established in terms of citizenship and the public sphere.

At this point, it may be useful to recall Michael Oakeshott's distinction between civil associations and enterprise associations. While the latter are characterised by a teleological motive, the former are defined by an 'absence of such a purpose or choice' (Oakeshott, 1975: 158), which allows a legal system to set the conditions for individuals to strive and pursue their own interests. Autonomy within an enterprise association is intrinsically linked to consent and its removal ('freedom here is conceptually tied to the choice to be and to remain associated', Oakeshott, 1975: 158); in contrast, civil liberty concerns making individual decisions within a given political framework.

In liberal secession theories such as Beran's, affiliation with a state is an important part of individual freedom of choice. Secessionists would argue that this aspect is not related to the pursuit of a common goal, as in the case of Oakeshott's enterprise associations; rather, it is related to granting the possibility of choosing the framework within which individual liberty is exercised. However, in a scenario where small sovereign units dominate the political landscape, the reality would be a politicisation of these 'last links' and, therefore, a granting of a deeper meaning to relationships that previously did not bear it.

The construction of large state structures and their corresponding societies opened a space for individuals to flourish. In contrast, interpreting the concept of society in terms of matrimonial cohabitation or labour relations would make that space, paradoxically, less free. In our view, a reductionist understanding of liberalism that does not consider the different contingencies on which freedom is ultimately based leads to new logics of association that would prove corrosive to the space in which modern liberties evolved. 


\section{Catalan Nationalism and the Creation of Tabarnia}

In pursing an objective, political arguments tend to adapt to the moral context of their time to seek the support of public opinion. In this way, the discourse of Catalan separatist nationalism has clearly changed the ethnos' right to self-determination for the demos' right to freedom of association (Lehning 1998: 8-10).

Secession is now justified in the media not by the right of complete political autonomy for an ethnic community but by the notion that state affiliation should ultimately rest in citizens' consent. The ideal way to measure consent is, of course, the celebration of a referendum on self-determination. Since the failed attempt to hold such a referendum on 1 October 2017 - blocked by Spanish police - claims that link democracy and 'sovereignism' are ubiquitous throughout the Catalan political landscape. Their aim is to depict a face-off between freedom and authoritarianism. In this fight, the nationalist movement does not defend secession outright but a 'right to decide', thus rallying the support of not only those in favour of independence but also those in favour of holding a vote on the matter (that is, 'non-separatist sovereignists'). In very few cases, however, is the liberal idea according to which the smaller the sovereign unit, the more democratic the configuration of boundaries - or any other justification of why Catalonia should be the sovereign delimitation subject to popular consultation - mentioned.

Thus, regarding the Catalan case, we see a mingling of liberal secession theories and nationalist arguments in politics and the media and even within the scientific community. One outcome is that liberal concepts are being exploited for nationalist purposes. Ironically, those in Catalonia who favour secession and adopt arguments from the liberal theory of secession to make their point support and discriminate against the public use of the Spanish language even though Catalan society today is practically 
bilingual. The regional government's policy is to impose the Catalan language in the educational system against the will of a considerable number of both parents and students. Local shops already face fines if they label their services in Spanish and not in Catalonian. Therefore, both the secessionists' policy proposals and their implementation are not very liberal but, rather, are nationalist: They represent not the free association of fellowlanguage speakers but the integration of all citizens in a new political community defined in cultural terms. In particular, this situation poses challenges to the liberal theory of secession when comparing the Catalan linguistic example with the cases of Belgium and Quebec. In the latter, we see separate communities with corresponding diverging competences in their respective second language; however, in the former, the vast majority are able to properly speak and read in both official languages.

The case of Catalonia thus shows that local secessionists are not generally moved by considerations of free association but by the vision of a national community whose cultural links are considered more legitimate than those of political competitors. In other words, it is not about free association aimed at constructing a society based on consent but an alleged national community that seeks to restore (i.e., its legitimacy lies in the past) a previously usurped reality. Some who claim that their goals are backed by the liberal theory of secession do indeed pursue policies that contradict its spirit.

We believe that the liberal ideal is met on the occasion of Catalonia forming part of the Spanish state that functions in the manner of an Oakeshottian civil association as a device to guarantee Catalans their freedom to associate according to their linguistic preferences, rather than in the form of a new Catalan state that, with its acquired political powers, backs the transformation of a bilingual community into a monolingual community. In our opinion, this phenomenon is a paradoxical effect that the liberal theory of secession entails: The politisation of the link between individuals and the political unit 
to which they belong makes it more difficult for diverging ideas, languages, or cultures to remain within the same political framework - with the result that states become less pluralistic political units. The free and conscious decision of belonging to a given political unit would then resemble the choice of a political ideology, resulting in a backlash against the integrative vocation of modern pluralist states.

All these motives underlie the emergence of the fictional region Tabarnia, a creation of non-secessionist Catalan citizens. Its virtual territory includes the urban parts of the Catalan coast, where only a minority of citizens support secessionism (Barcelona, its periphery, and Tarragona), although activism is mainly carried out on social media. In a bid to counter the attack of Catalan nationalism, the new territory's followers use their rivals' arguments to justify the project: 1) Tabarnia's supporters want a democratic right to decide their own independence from Catalonia; 2) they claim that Tabarnia is discriminated against in financial terms vis-à-vis the Catalan hinterland; 3) and, finally, they allege that while the secessionists' Catalonia is rural, conservative and closedminded, they represent the cosmopolitan, advanced and open-minded part of the region.

Some of Tabarnia's supporters trace its founding moment back to the medieval county of Barcelona, which we believe is an unnecessary historic argument that obscures the fundamental point: If secessionists defend their project of an independent Catalonia on liberal and not nationalist grounds, then they are impelled to grant a right to secession to territorial communities such as Tabarnia. In fact, Catalan secessionism affirms the right to sovereignty of the historic region Valle de Arán (a small territory in the Pyrenees with certain unique cultural patterns). However, the underlying motive in this case may lie instead in an anticipatory move to immunise their own movement against accusations of incoherence by granting the right to secession to a historic community that represents only a small piece of Catalan territory. 
Therefore, the real test for the liberal argument in the case of Catalonia would be the granting of 'the right to decide' for territorial communities not because of their coincidence with any historic terrain but because of their rejection of the creation of a new Catalan state - especially if it were Barcelona, Catalonia's economic, symbolic and urban centre. Were this the case, we would see Brenan's prediction regarding his theory of secession become reality: a landscape of state pluralism and territorially discontinued states.

Let the separatist movement specify the area in which a plebiscite is to be held, e.g. North Wysteria. Assume there is a majority for secession and that secession is granted in principle. Now any area of North Wysteria must in turn be permitted to vote on whether it wishes to secede from North Wysteria (and stay with what is left Wysteria, if they wish) (Beran, 1984, 29).

The general public's uncertainty regarding whether the Tabarnia phenomenon constitutes satire or is indeed a serious political proposal illustrates that we are still far away from thinking about political units in the way in which the liberal theory of association suggests. This does not mean, however, that the virtual territory '[...] is clearly a provocation, and not even a very intelligent one at that. It trivialises the notion of identity, treating it as if it is something as pedestrian as changing clothes' (Tsavkko García 2018), an opinion that some international media seem to share. On the contrary, Tabarnia is a welcome test case for checking the liberal promises of Catalan secessionism, ultimately revealing its basic nationalism.

In addition, it inspires us to think about another remarkable point: In a territory as polarised as Catalonia is today, identities tend to be shaped by politics rather than by culture. Consequently, the logic of association that most respects its members' identity 
would separate between nationalists and non-nationalists. The ridiculing criticism of Tabarnia's symbolic nation-building (it already has a flag, a seal, etc.) on the grounds that it lacks a retrospective narrative is a criticism of nationalist motives that contradict the liberal mindset. ${ }^{2}$

Thus, after it had been possible to imagine national communities in modern times owing to a 'half-fortuitous, but explosive, interaction between a system of production and productive relations (capitalism), a technology of communications (print), and the fatality of human linguistic diversity' (Anderson 2006: 46), perhaps it is now the time for internet-based interaction to facilitate the advent of different types of communities based on different types of human affinities. Tabarnia may be just one of its first adumbrations.

\section{References}

Anderson, B. 2006. Imagined Communities: Reflections on the Origin and Spread of

Nationalism. 2nd edn. rev. London: Verso.

Beran, H. 1977. 'In Defense of the Consent Theory of Political Obligation and Authority', Ethics 87, 3: 260-271.

Beran H. 1984. 'A Liberal Theory of Secession', Political Studies 32, 1: 21-31.

\footnotetext{
${ }^{2}$ In draft bill C-341 presented by Stephen Harper, section five concerns the possibility of including an additional question in the Québécois referendum on independence from Canada: 'If Quebec separates from Canada, should my community separate from Quebec and remain a part of Canada?' (Bill C-341, 5) 2b. http://www.parl.ca/DocumentViewer/en/35-2/bill/C-341/first-reading/page-16 See also Gouëset (2018).
} 
Beran H. 1994. 'The place of secession in liberal democratic theory', in P. Gilbert and P. Gregory (eds.), Nations, Cultures and Markets, Aldershot: Avebury.

Beran, H. 1998. 'A democratic theory of political self-determination for a new world order', in P. B. Lehning (ed.), Theories of Secession, London: Routledge.

Buchanan, A. 1991. The Morality of Political Divorce from Fort Sumter to Lithuania and Quebec. London: Routledge.

Buchanan, A. 2003. 'The Making and Unmaking of Boundaries: What Liberalism has to say', in Buchanan and M. Moore (eds.), States, Nations and Borders. The Ethics of Making Boundaries. Cambridge: Cambridge University Press.

Gouëset, C. 2018. 'Tabarnia: et si Barcelone devenait indépendante de la Catalogne séparatiste?' https://www.lexpress.fr/actualite/monde/europe/tabarnia-et-si-barcelone-devenait-independantede-la-catalogne-separatiste_1973252.html (Accessed 1 September 2018).

Kedourie, E. 1960. Nationalism, London: Hutchison \& Co.

Kymlicka, W. 2001. 'Territorial Boundaries: A Liberal Egalitarian Perspective', in D. Miller and S. H. Hashmi (eds.), Boundaries and Justice: Diverse Ethical Perspectives, Princeton and Oxford: Princeton University Press,

Lehning, P. B. 1998. 'Theories of secession: an introduction', in Lehning (ed.), Theories of Secession, London: Routledge.

McGee R. W. 1992. 'A Third Liberal Theory of Secession', Liverpool Law Review 14, 1: 45-66.

Mill, J.S. 1977 [1861]. 'Considerations on Representative Government, XVI' in J. M. Robson (ed.), Collected Works of John Stuart Mill, Vol. XIX. Toronto and Buffalo: University of Toronto Press. 
Miller D. 2003. 'Liberalism and Boundaries: A Response to Allen Buchanan', in A. Buchanan and M. Moore (eds.), States, Nations and Borders. The Ethics of Making Boundaries, Cambridge: Cambridge University Press.

Oakeshott M. 1975. On Human Conduct, Oxford: Oxford University Press.

Tsavkko García, R. 2018. 'Tabarnia: A not-so-funny joke on Catalan democracy', https://www.aljazeera.com/indepth/opinion/tabarnia-funny-joke-catalan-democracy180208073352611.html (Accessed 1 September 2018). 